\title{
Hepatoprotective Activity of Plant Peptides
}

\author{
O. G. Kulikova1, D. I. Maltsev' ${ }^{1}$, A. P. Ilyina', V. P. Yamskova², I. A. Yamskov ${ }^{1}$ \\ ${ }^{1}$ A. N. Nesmeyanov Institute of Organoelement Compounds of Russian Academy of Sciences, Moscow, Russia \\ ${ }^{2}$ Koltzov Institute of Developmental Biology of Russian Academy of Sciences, Moscow, Russia \\ Email: koulikova_olga@mail.ru
}

Received 5 November 2014; accepted 6 April 2015; published 13 April 2015

Copyright (C) 2015 by authors and Scientific Research Publishing Inc.

This work is licensed under the Creative Commons Attribution International License (CC BY).

http://creativecommons.org/licenses/by/4.0/

c) (i) Open Access

\begin{abstract}
Peptides (molecular weights are 1200 - 11,600 Da) biologically acting at concentration $10^{-8}$ - 10-15 $\mathrm{mg} / \mathrm{ml}$ were obtained from leaves of dill Anethum graveolens $\mathrm{L}$. and celandine Chelidonium majus L. by circular dichroism (CD) spectroscopy. We have shown that these peptides form second structure characterized by the prevalence of $\beta$-structures and coil in water solution. In model of organotypic roller culturing of triton liver in vitro, the ability of the peptides isolated from Anethum graveolens $\mathrm{L}$. and Chelidonium majus $\mathrm{L}$. at concentration $10^{-8}-10^{-15} \mathrm{mg} / \mathrm{ml}$ to influence increasing of pigment cells, which provided protective function of organism, was demonstrated.
\end{abstract}

\section{Keywords}

Peptides, Medical Plants, Organotypic Roller Culturing, Newt Liver

\section{Introduction}

Plants are commonly used as the traditional source of biologically active compounds, most of which are not studied and characterized enough [1] [2]. The search and study of biologically active compounds that determine medicinal properties of plants are still a relevant problem. Although medicinal plants contain different groups of biologically active compounds, such as vitamins, flavonoids, terpenes, phytoncides, glycosides, etc., the question as to which compounds determine the efficiency of using some plants for prophylaxis and treatment of certain pathologies remains to be answered. Different kinds of biologically active substances play an important role in biological properties of medicinal plants. New biologically active membranotropic homeostatic tissue specific bioregulators (MHTBs) which are found in different tissues of mammals, plants and fungi are among compounds influencing important biological processes such as migration, adhesion, proliferation, and cell differentiation. The feature of MHTBs is to stimulate restoration and reparation in the pathologically modified tissues and their biological activity is characterized with the absence of species, but the presence of the tissue specificity [3]. MHTBs are located in intercellular space of tissues and have a complex structure consisting of biologically ac- 
tive peptides and modulator proteins, influencing the biological action of peptides [3]-[8]. All members of this group bioregulators have similar physical and chemical properties [3]. Thus, for isolating these MHTBs from different tissue sources and for their purification we use experimental approach including different methods of their extraction from tissues and the range of traditional biochemistry methods.

The aim of this work was to isolate peptides from extract of leaves of Anethum graveolens L. and Chelidonium majus L. and to study their hepatoprotective biological activity in model of organotypic roller culturing of triton liver in vitro.

Dill (Anethum graveolens) is an annual herb in the celery family Apiaceae. It is the sole species of the genus Anethum. Celandine Chelidonium majus L. is an annual herb in the celery family Papaveraecae. Anethum graveolens $\mathrm{L}$. and Chelidonium majus L. are herbaceous plants, which are widely used as food additives. They contain essential oils and fat, water, protein, carbohydrate, and various minerals. In addition, drugs made of $\mathrm{A}$. graveolens and Chelidonium majus L. possess antibacterial, antispasmodic, and hepatoprotective properties [9] [10].

\section{Materials and Methods}

Dill (Anethum graveolens L.) and celandine (Chelidonium majus L.) were obtained from the nursery garden of the Tsitsin Main Botanical Garden, Russian Academy of Sciences. Reagent used in the study were of reagent purity grade and included acetonitrile, ammonium sulfate, ammonium nitrate, potassium nitrate, hydrate of magnesium sulfate, potassium phosphate, hydrate of calcium chloride, sodium aside (chemically pure), culturing medium 199 and bidistilled water (16 Mom). Investigation of biological activity was carried out using newts Pleurodeles waltl liver which were kept in standard conditions at the Koltsov Institute of Developmental Biology (Russian Academy of Sciences). In the study, we used an Assistant RM5 roller (Germany). Samples were centrifuged in a T 32A centrifuge (Janetzky, Poland).

Obtaining of extracts and supernatants of plants tissues. For extraction, we used $3500 \mathrm{~g}$ of fresh leaves of dill Anethum graveolens L. and $3500 \mathrm{~g}$ of fresh leaves of celandine Chelidonium majus L., cut into small (1 - 1.5 $\mathrm{cm}$ ) fragments, which were incubated at $4^{\circ} \mathrm{C}-5^{\circ} \mathrm{C}$ for $5-6 \mathrm{~h}$ in an extraction solution containing $2.06 \times 10^{-2} \mathrm{M}$ $\mathrm{NH}_{4} \mathrm{NO}_{3}, 1.88 \times 10^{-2} \mathrm{M} \mathrm{KNO}_{3}, 3 \times 10^{-2} \mathrm{M} \mathrm{CaCl}_{2} * 2 \mathrm{H}_{2} \mathrm{O}, 1.5 \times 10^{-3} \mathrm{M} \mathrm{MgSO}_{4}-7 \mathrm{H}_{2} \mathrm{O}, 1.25 \times 10^{-3} \mathrm{M} \mathrm{KH}_{2} \mathrm{PO}_{4}$. Thus obtained extracts were centrifuged at $3000 \mathrm{~g}$ for $30 \mathrm{~min}$; the pellets were discarded. Then, dry ammonium sulfate was added to the plant extracts under stirring to a concentration of $780 \mathrm{~g} / 1$ until a saturated salt solution formed; $\mathrm{pH}$ was adjusted at $7.5-8.0$ with ammonium hydroxide. The obtained protein mixtures were incubated at $4^{\circ} \mathrm{C}$ for $95-100 \mathrm{~h}$. The precipitated proteins were separated by centrifugation at $25,000 \mathrm{~g}$ and $4^{\circ} \mathrm{C}-8^{\circ} \mathrm{C}$ for $30 \mathrm{~min}$. Thus, obtained supernatants were dialyzed against water until complete removal of ammonium sulfate and then concentrated at $37^{\circ} \mathrm{C}-40^{\circ} \mathrm{C}$ in a vacuum rotor evaporator.

Protein concentration was determined by the Lowry's method.

Mass-spectrometric analysis. Molecular weights of peptides were determined by the matrix-assisted laser desorption/ionization (MALDI-TOF) technique in an Ultra Flex 2 time-of-flight mass spectra were recorded in a linear model and reflecting mode. Samples for mass-spectrometric analysis were obtained by evaporating until dry with subsequent dilution in $70 \%$ acetonitrile containing $0.1 \%$ trifluoroacetic acid with $\alpha$-cyano-4-hydroxycynamic acid being used as a matrix.

Circular dichroism spectroscopy. The CD spectra were collected of far-UV spectra at $1 \mathrm{~nm}$ intervals using average times $2 \mathrm{~s}$. The final spectra were obtained by averaging the results of three scans and subtracting the spectrum of baseline (control). The content of secondary structures elements was evaluated using the program CDNN.

SDS-Electrophoresis of protein in polyacrylamide gel. Electrophoresis in $15 \%$ polyacrylamide gel was performed according to Laemmli [11]. Coomassie G-250 was used for gels staining.

Reversed phase HPLC. Plant supernatants were analyzed using a high-pressure chromatograph (Agilent 1100, United States) equipped with a Kromasil C8 hydrophobic column $(4.6 \times 250 \mathrm{~mm})$ (Russia). Elution was conducted in a gradient of concentration of acetonitrile (5\% - 95\%) in $0.1 \%$ trifluoroacetic acid (pH 2.2) with velocity $0.3 \mathrm{ml} / \mathrm{min}$ for $55 \mathrm{~min}$. Detection was carried out at $280 \mathrm{~nm}$.

Organotypic roller culturing of newt liver in vitro. Newts were anesthetized in $2 \%$ ethyl urethane prepared in saline for amphibians $(0.65 \% \mathrm{NaCl})$ or in $0.1 \% \mathrm{MS}-222$ solution (Sigma, Germany). Then, the newts were rinsed in ethanol and decapitated. The liver was surgically removed, $3 \times 3 \times 3$ fragments were taken from the 
central lobe, transferred into a nutrient medium for amphibian, and cultured at $21^{\circ} \mathrm{C}-23^{\circ} \mathrm{C}$ in dark-glass vials. For each experiment liver fragments from one newt were used for different experimental series and control. The medium for tissue culturing contained $70 \mathrm{ml}$ of medium 199, $10 \mathrm{ml}$ of fetal calf serum, $30 \mathrm{ml}$ of boiled doubly distilled water, and $200 \mu \mathrm{l}$ of $4 \%$ gentamycin sulfate. The medium was subjected to cold sterilization through type CA membrane filters (pore size, $0.2 \mu \mathrm{m}$; Nal-gene, United States). Culture medium (4 ml) was supplemented with $40 \mu \mathrm{l}$ of fractions isolated from the Anethum graveolens L. and Chelidonium majus L., in experimental series and with $40 \mu \mathrm{l}$ of distilled water in the control series. All flasks were closed under sterile conditions and then cultured by rotating in a roller at $22^{\circ} \mathrm{C}$ for 3 days.

\section{Results and Discussion}

Fractions of small peptides were obtained from dill Anethum graveolens L. leaves extract and celandine Chelidonium majus L.) extract according to an earlier developed method [3]. Then plant supernatants were studied by SDS-PAGE. It was shown that plant supernatants contain protein component in molecular weights ranges less than $14.2 \mathrm{kDa}$ (Figure 1).

By CD spectroscopy, we have investigated secondary structures of peptides fractions. Using program CD deconcovolution we calculated elements of secondary structures formed by peptides. According to calculation secondary structure formed by peptides isolated from Anethum graveolens L. contains about $29.8 \% \pm 0.5 \%$ of $\alpha$-helix, $42.7 \% \pm 0.5 \%$ of $\beta$-turns and $24.8 \% \pm 0.5 \%$ of coils. Secondary structure formed by peptides isolated from Chelidonium majus L. contains $8.1 \% \pm 0.5 \%$ of $\alpha$-helix, $79.1 \% \pm 0.5 \%$ of $\beta$-structure and $16.7 \% \pm 0.5 \%$ of coil.

Thus, by method of CD spectroscopy we have shown that plant peptides in water solution form secondary structure characterized by the prevalence of $\beta$-elements.

Separation of peptide containing fractions by reversed phase HPLC yielded fractions of different retention time (Figure 2 and Figure 3). Each of these fractions was collected and analyzed by MALDI-TOF mass spectrometry. MALDI-TOF mass spectrometric analysis of these HPLC-fractions revealed peptides with molecular weights of 1800-4600 Da (Anethum graveolens L.) and 1200 - 11,600 \pm 2 Da (Chelidonium majus L.) (Figure 4 and Figure 5).

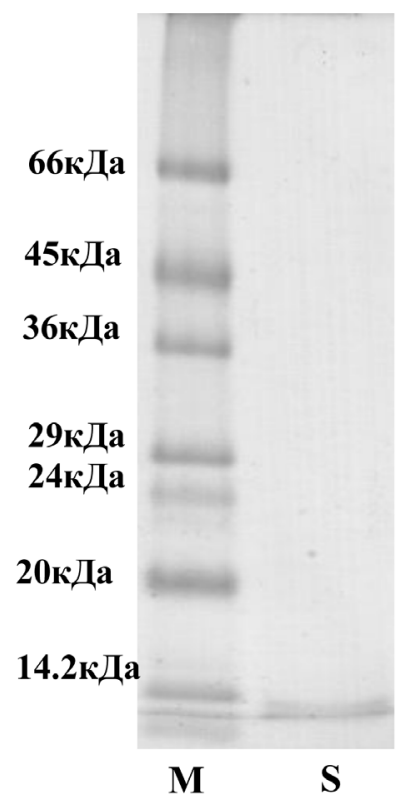

Figure 1. SDS-PAGE of peptide fraction of Anethum graveolens L. in 15\% polyacrylamide gel. Staining with Comaassie Brilliant Blue G-250. Markers: $\alpha$-lactalbumin—14,200 Da, trypsin soybean inhibitor-20,000 Da, trypsinogen from pancreas bovine - 24,000 Da, carbonic anhydrase-29,000 Da, glyceraldegyde-3-phosphathydrogenasa - 36,000 Da, ovalbumin - 45,000 Da, albumin-66,000 Da. S-peptide fraction. 


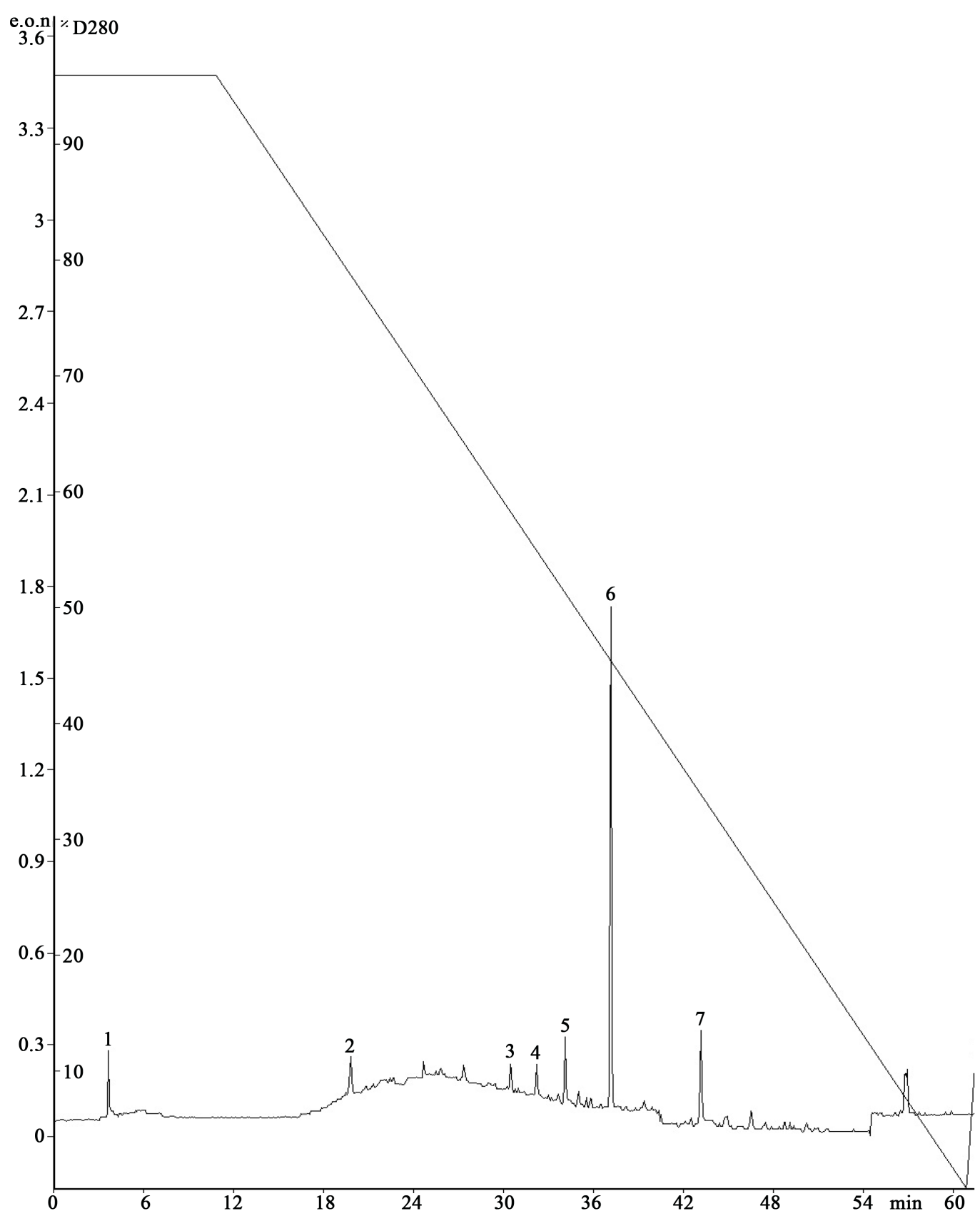

Figure 2. Separation of Anethum graveolens L. supernatant using phase HPLC equipped with Kromasil C18 column $(4.6 \times 250 \mathrm{Mm})$ (Russia). Elution was carried out in a concentration gradient of acetonitrile $(5 \%-100 \%)$ in $0.1 \%$ trifluoroacetic acid ( $\mathrm{pH} \mathrm{2.2)}$ and velocity of $0.5 \mathrm{ml} / \mathrm{min}$ for $55 \mathrm{~min}$. Detection at $280 \mathrm{~nm}$.

According to the literature [9] [10] Anethum graveolens L. and Chelidonium majus L. are the plants which characterized by the hepatoprotective activity. In early study [7] we have shown that peptides obtained from plantain Plantago major L. by using these experimental approach are responsible for wound healing activity of this plant. In our research, we decided to demonstrate that peptides isolated from Anethum graveolens L. and Chelidonium majus L. are responsible for their hepatoprotective activity. For this purpose we use model of organotypic roller culturing of newt Pleurodeles waltl liver in vitro. This model is used for researching of hepatoprotective effect of peptides [12]. Area of pigmented cells is the main parameter indicating the activation of the protective properties of liver tissue cells. In literature, these pigment cells are considered as analogs of the Kupffer 


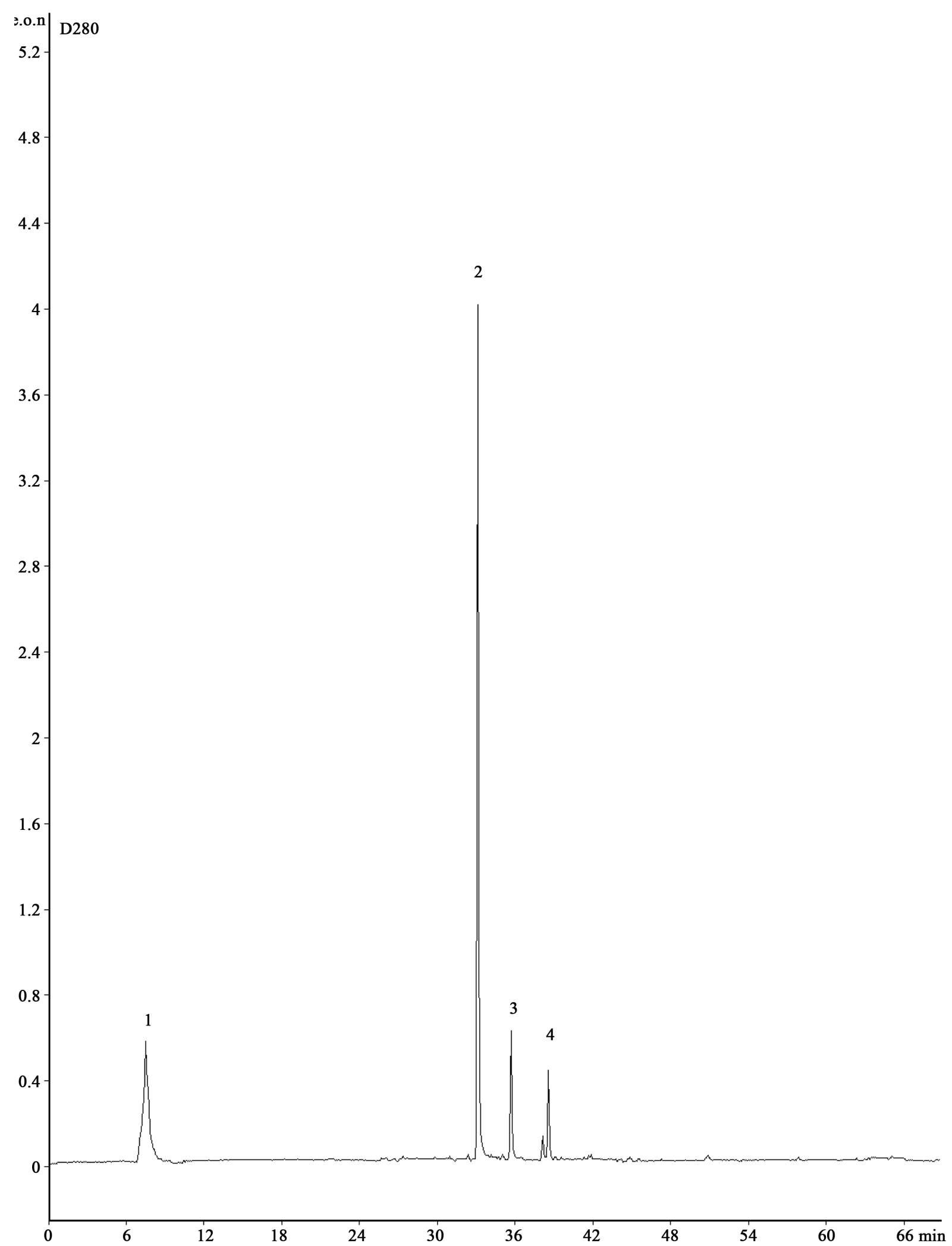

Figure 3. Separation of Chelidonium majus L. supernatant using phase HPLC equipped with Kromasil C18 column $(4.6 \times$ 250 мм) (Russia). Elution was carried out in a concentration gradient of acetonitrile $(5 \%-100 \%)$ in $0.1 \%$ trifluoroacetic acid (pH 2.2) and velocity of $0.5 \mathrm{ml} / \mathrm{min}$ for $55 \mathrm{~min}$. Detection at $280 \mathrm{~nm}$. 


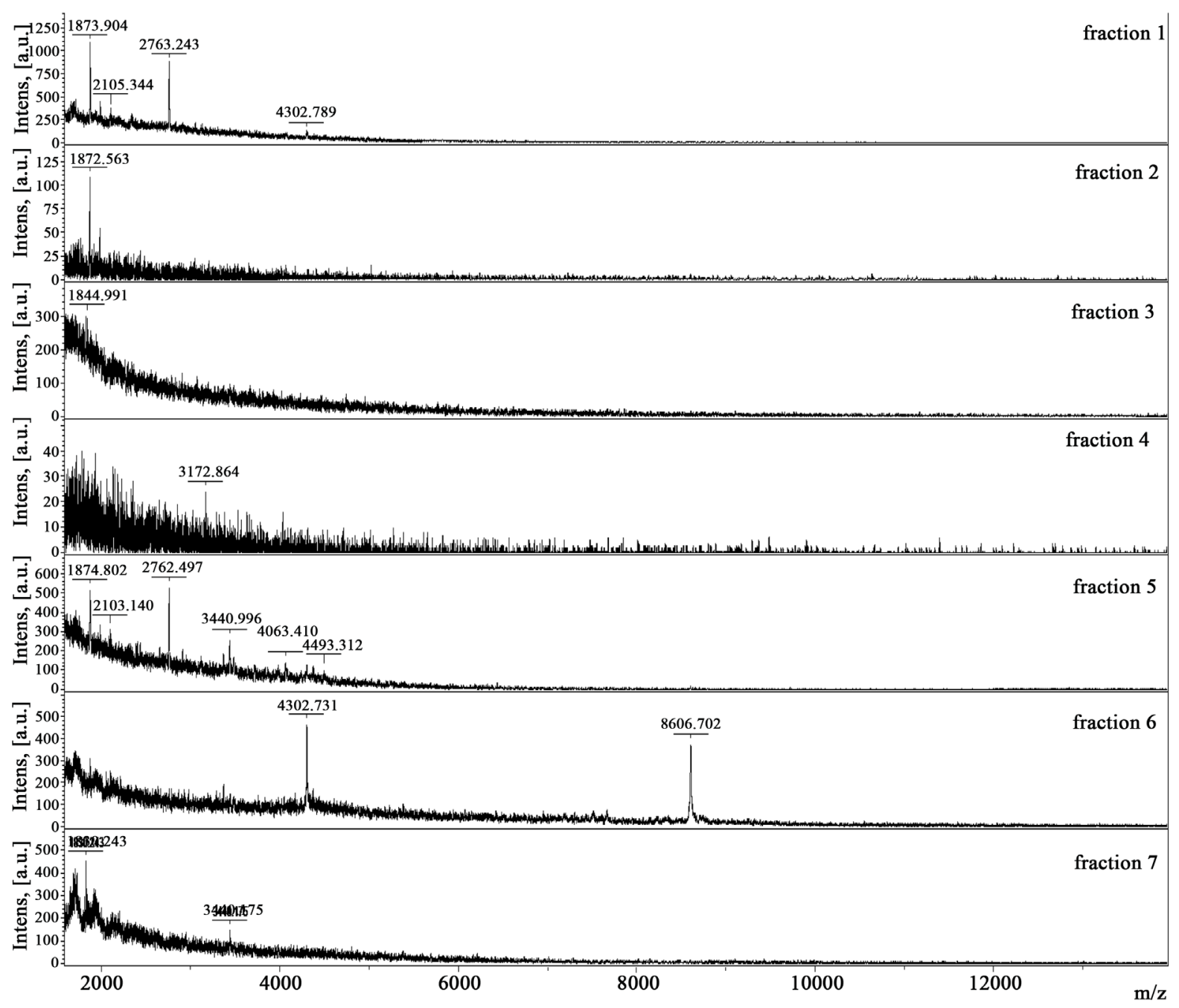

Figure 4. MALDI-TOF mass spectrometry analysis of HPLC fraction of Anethum graveolens L.

cells of mammals tissue. Pigment cells are provide protective function of organism under the intoxication, infections by absorbing different particles such as viruses, bactria, pigments and others [13] [14].

In present work the effect of peptides isolated from Anethum graveolens L. and Chelidonium majus L. on condition of amphibian liver tissue assessed by the area of pigment cells and condition of tissue.

After 3 days of culturing of liver tissue with adding to the medium culture plant peptides, we can observe clusters of pigment cells, which area statistically significant exceeds the area in control series as well as in native tissues (Table 1 and Figure 6). It should be also noticed the maintenance of tissue structure in case of plant peptides action. In comparison with control there, we can see conservation of adhesive interaction between cells, activity of hematogenesis zone (cortical layer and circumvascular area). Pigment cells under peptides treatment form a large clusters in comparison with control and native series (Figure 6(c) and Figure 6(d)). This experiment has shown that plant peptides at concentration $10^{-8}-10^{-15}$ are able to activate newt liver pigment cells which provide protective function of organ. This type of pigment cells activation was observed at the amphibian premises in adverse condition. For example, hypoxia, intoxication, trauma and seasonal changes provide significant increasing of pigment cells area in liver [13].

\section{Conclusion}

Thus, in spite of a great number of studies of plant peptides we can conclude that peptides obtained from Anethum graveolens L. and Chelidonium majus L. in this work are differed. In the model of newt liver we can see 


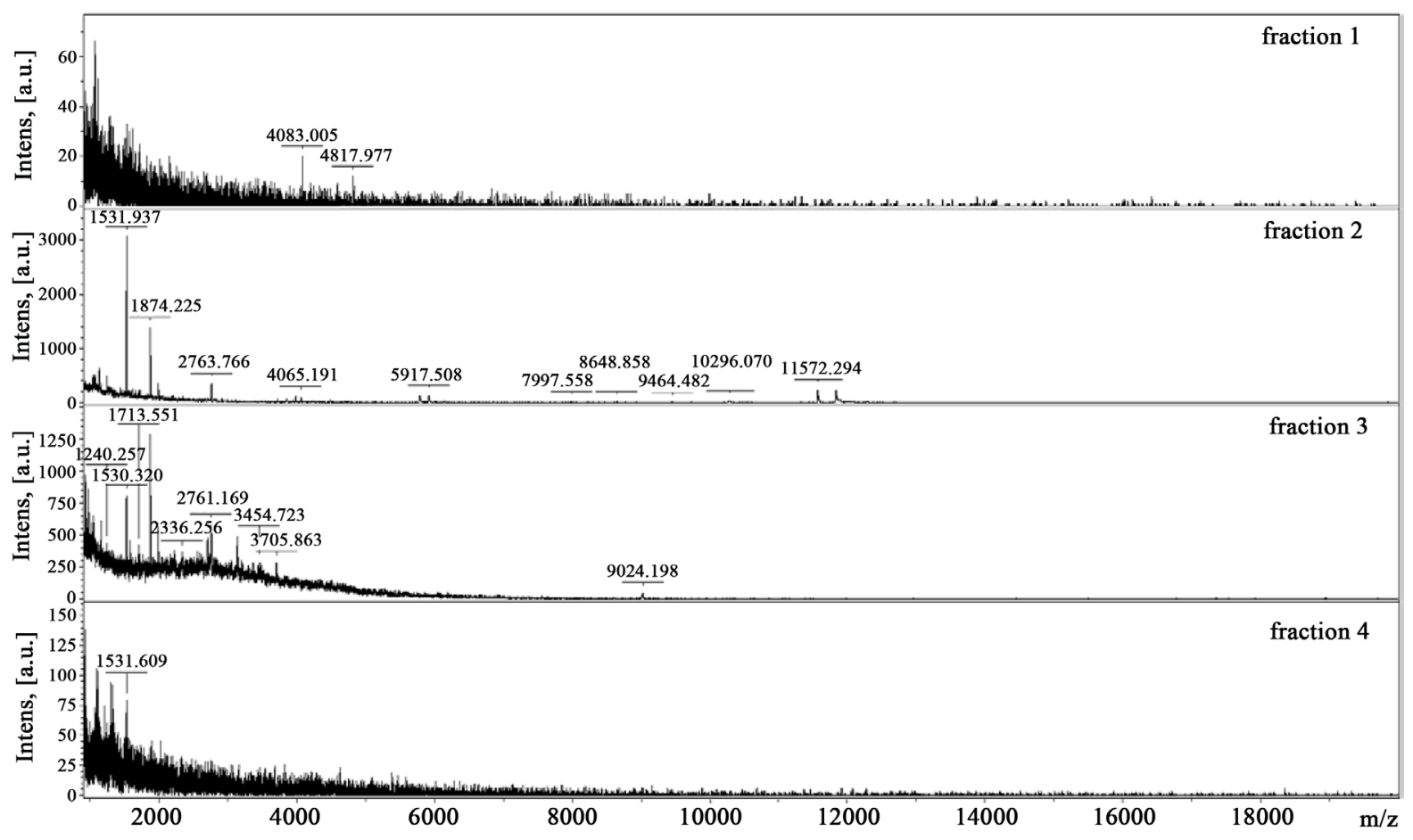

Figure 5. MALDI-TOF mass spectrometry analysis of HPLC fraction of Chelidonium majus L.

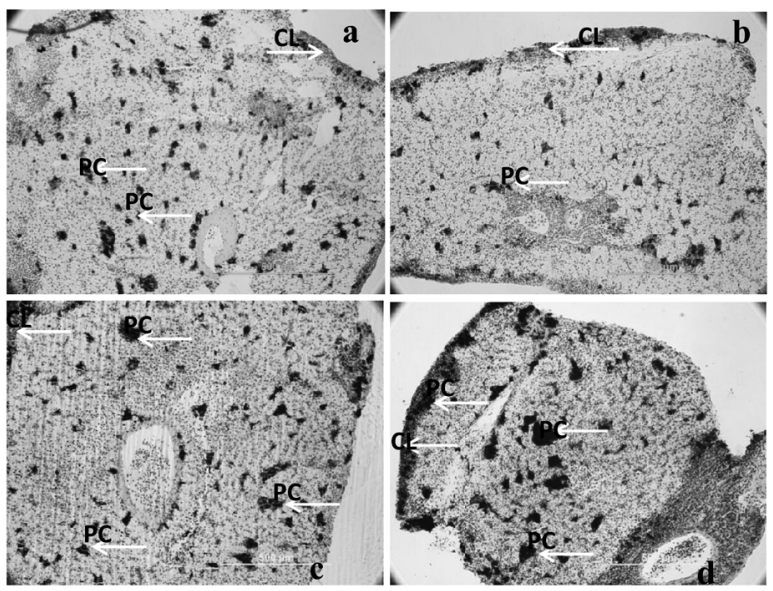

Figure 6. Histological slices of newt Pleurodeles waltl liver after organotypic roller culturing: a-native tissue; b-control (without adding peptides); c-treatment with peptides from Chelidonium majus L.; d-treatment with peptides from Anethum graveolens L. PC-pigmented cells; CL-cortical layer.

Table 1. The results of organotypic roller culturing of newt liver.

\begin{tabular}{ccc}
\hline Tissue & Description & $\begin{array}{c}\text { The area of pigment cells } \\
(\% \text { of the total area of histological slice) }\end{array}$ \\
\hline Native tissue & Non treatment tissue & $7.1 \pm \mathbf{1 . 4}$ \\
Control & Culturing without any addings & $\mathbf{5 . 8} \pm \mathbf{1 . 3}$ \\
Experiment 1 & $\begin{array}{c}\text { Culturing under adding peptides isolated } \\
\text { from Chelidonium majus L. }\end{array}$ & $\mathbf{6 . 7} \pm \mathbf{1 . 4}(\mathbf{p}<\mathbf{0 . 0 5})$ \\
Experiment 2 & $\begin{array}{c}\text { Culturing under adding peptides } \\
\text { isolated from Anethum graveolens L. }\end{array}$ & $\mathbf{9 . 0} \pm \mathbf{3 . 7}(\mathbf{p}<\mathbf{0 . 0 5})$ \\
\hline
\end{tabular}


that the results of this investigation let us assume that this plant peptides are responsible for hepatoprotective activity of the plant from which they are isolated. So, medical properties of dill Anethum graveolens L. and celandine Chelidonium majus L. can be explained in terms of these small peptides. Our future research in this field will devote to structures of these biological active peptides. Using method of amino acid analysis and determination of primary structure by sequence analysis can make us realize the connection between structures and properties of studied peptides. Structural and functional properties of plant peptides provide more effective use of them.

\section{References}

[1] Olennikov, D.N., Tanshaeva, L.M. and Michailova, T.M. (2005) Organic Acid of Official Plants. Chemistry of Natural Compounds, 4, 354-355.

[2] Masoomeh, S.G., Shokoohamiri, M.R., Amirrajab, N., Behnaz, M., Ali, G., Farideh, Z., Golnar, S. and Mehdi, R.A. (2006) In Vitro Antifungal Activities of Allium cepa, Allium sativum and ketoconazole against Some Pathogenic Yeasts and Dermatophytes. Fitoterapia, 77, 321-323. http://dx.doi.org/10.1016/j.fitote.2006.03.014

[3] Yamskova, V.P., Krasnov, M.S. and Yamskov, I.A. (2012) New Experimental and Theoretical Aspects of Bioregulation. Action Mechanism of Membranotropic Homeostatic Tissue-Specific Bioregulators. Lambert Academic Publishing, Saarbrucken, $136 \mathrm{p}$.

[4] Borisenko, A.V., Yamskova, V.P., Krasnov, M.S., Blagodatskikh, I.V., Vecherkin, V.V. and Yamskov, I.A. (2007) Regulatory Proteins from the Mammalian Liver That Display Biological Activity at Ultra Low Doses. In: Varfolomeev, S.D., Burlakova, E.B., Popov, A.A. and Zaikov, G.E., Eds., Biochemical Physics Frontal Research, Nova Science Publishers Inc., Hauppauge, 35-46.

[5] Margasyuk, D.V., Krasnov, M.S., Blagodatskikh, I.V., Grigoryan, E.N., Yamskova, V.P. and Yamskov, I.A. (2007) Regulatory Protein from Bovine Cornea: Localization and Biological Activity. In: Varfolomeev, S.D., Burlakova, E.B., Popov, A.A. and Zaikov, G.E., Eds., Biochemical Physics Frontal Research, Nova Science Publishers Inc., Hauppauge, 47-60.

[6] Yamskova, V.P., Krasnov, M.S., Rybakova, E.Yu., Vecherkin, V.V., Borisenko, A.V. and Yamskov, I.A. (2007) Analysis of Regulatory Proteins from Bovine Blood Serum That Display Biological Activity at Ultra Low Doses: 2. Tissue Localization and Role in Wound Healing. In: Varfolomeev, S.D., Burlakova, E.B., Popov, A.A. and Zaikov, G.E., Eds., Biochemical Physics Frontal Research, Nova Science Publishers Inc., Hauppauge, 71-78.

[7] Krasnov, M.S., Yamskova, V.P., Kulikova, O.G., Ilyina, A.P., Margasyuk, D.V., Rybakova, E.Yu. and Yamskov, I.A. (2011) Study of New Bioregulators Isolated from Plantago majus L. Applied Biochemistry and Microbiology, 47, 146153.

[8] Kulikova, O.G., Yamskova, V.P., Ilyina, A.P., Margasyuk, D.V., Molyavka, A.A. and Yamskov, I.A. (2011) Identification of a New Bioregulators Acting in Ultra-Low Doses in Bulb Onion. Applied Biochemistry and Microbiology, 47, $1-5$.

[9] Jana, S. and Shekhawat, G.S. (2010) Anethum graveolens: An Indian Traditional Medicinal Herb and Spice. Pharmacognosy Review, 4, 179-184. http://dx.doi.org/10.4103/0973-7847.70915

[10] Gilca, M., Gaman, L., Panait, E., Stoian, I. and Atanasiu, V. (2010) Chelidionium majus-An Integrative Review: Traditional Knowledge versus Modern Findings. Forschende Komplementarmedizin, 17, 241-248. http://dx.doi.org/10.1159/000321397

[11] Laemmli, U.K. (1970) Nature.

[12] Malcev, D.I., Yamskova, V.P. and Yamskov, I.A. (2012) Tissue Specificity Study of Bioregulators Isolated from Liver and Lung of Mammals. Journal of Information, Intelligence and Knowledge, 4, 3-9.

[13] Corsaro, C., Scalia, M., Leotta, N., Mondio, F. and Sichel, G. (2000) Characterization of Kupffer Cells in Some Amphibia. Journal of Anatomy, 196, 249-261. http://dx.doi.org/10.1046/j.1469-7580.2000.19620249.x

[14] Sichel, G., Scalia, M. and Corsaro, C. (2002) Amphibia Kupffer Cells. Microscopy Research and Technique, 57, 477490. http://dx.doi.org/10.1002/jemt.10101 